\title{
ОРГАНИЗАЦИОННО-ПРАВОВОЕ ОБЕСПЕЧЕНИЕ ИНФОРМАЦИОННОЙ ОТКРЫТОСТИ ОРГАНОВ ГОСУДАРСТВЕННОЙ ВЛАСТИ В РОССИЙСКОЙ ФЕДЕРАЦИИ: СОВРЕМЕННОЕ СОСТОЯНИЕ И РЕЗУЛЬТАТЫ
}

\section{LEGAL ORGANIZATION OF INFORMATION OPENNESS OF STATE AUTHORITIES IN THE RUSSIAN FEDERATION: CURRENT STATE AND RESULTS}

T. Ivleva

Summary. This article discusses the concepts and essence of open government bodies of the Russian Federation. The analysis of normative legal acts that laid the foundation for the development of open state structures on the territory of our country is carried out. The goals and objectives of each of the legislative acts, the scope of its regulation and the corresponding mechanisms of information openness of the authorities are presented. Organizational and legal restrictions on the development of information openness were identified and relevant recommendations were made.

Keywords: information openness; public openness, information technologies, open government data; open government, digital transformation, digital economy.

\author{
Ивлева Татьяна Андреевна \\ Соискатель, Московский государственный \\ университет им. М.В. Ломоносова \\ Ivlevata96@gmail.com
}

Аннотация. В настоящей статье рассмотрены понятие и сущность информационной открытости органов государственной власти Российской Федерации. Проведен анализ нормативно-правовых актов, заложивших основу для развития информационной открытости государственных структур на территории нашей страны. Представлены цели и задачи каждого из законодательных актов, сферы его регулирования и соответствующие механизмы информационной открытости органов власти. Были выявлены организационно-правовые ограничения развития информационной открытости и внесены соответствующие рекомендации.

Ключевые слова: информационная открытость, открытость органов власти, информационные технологии, открытые государственные данные, открытое правительство, цифровая трансформация, цифровая экономика. $\mathbf{0}$ сновной тенденцией XXI века в России стало снижение уровня доверия граждан к органам государственной власти. По замерам социологических служб, в 2019-м году высокий рейтинг народного доверия сохранялся только в отношении военных структур - 63\%, рейтинг доверия к Президенту снизился до 58\%; к структурам же исполнительной и законодательной власти он был зафиксирован на уровне 33\% [1]. Это позволяет сделать вывод о том, что текущая модель государственного управления является недостаточно эффективной и вызывает заметное недоверие у граждан. Во многом это связано с непрозрачностью процесса принятия политических решений и политической жизни в целом, поскольку государственное управление в России традиционно является «закрытой» сферой. Тем временем, в развитых странах Запада открытость и транспарентность достаточно давно являются приоритетными принципами, на которых осуществляется трансформация традиционных форм и методов государственного управления, поскольку информационное общество XXI века формирует запрос на все большую открытость любых управленческих процессов.

Современные международные практики показывают, что одним из действенных способов формирования эффективного государственного управления, ориентированного на интересы и потребности граждан, служит повышение уровня его информационной открытости. Информационная открытость органов власти оказывает значительное влияние на развитие демократических процессов и вовлечение институтов гражданского общества в процесс принятия социально-значимых решений. Также она способствует более действенному контролю за деятельностью государственных структур, тем самым, способствуя решению 
таких проблем, как коррупция и экономическая преступность.

Изучение этой важной и актуальной тематики требует четкого понимания термина «информационная открытость». Однако в научной литературе данный термин широкого распространения не получил. В результате анализа многочисленных источников, относящихся к сфере обеспечения открытости управленческих процессов, нами был сформирован собственный подход к определению информационной открытости государственных структур. Под информационной открытостью органов государственной власти мы понимаем раскрытие сведений об аспектах деятельности органов власти, важных для общества, взаимодействие государственных структур с институтами гражданского общества по важным вопросам государственного управления, а также готовность органов государственной власти отвечать на требования и потребности граждан.

Выделяется три уровня открытости органов государственной власти [2]. На первом уровне обеспечивается простой доступ граждан к информации о деятельности органов государственной власти. При этом не обеспечивается обратная связь. На втором уровне появляется доступ к информации о принятии решений, причинах и факторах, которые на данный процесс влияют. И, наконец, на третьем уровне представители гражданского общества получают возможность участвовать в процессе принятия решений, заседая в советах и консультативных органах.

В настоящий момент в Российской Федерации государственные структуры начинают уделять все большее внимание внедрению технологий по развитию информационной открытости их деятельности. Важным критерием обеспечения качества их работы становится открытый доступ институтов гражданского общества к процессу принятия социально-значимых решений. Повышение эффективности информационного обеспечения, совершенствование методов и способов предоставления информации о государственном управлении Российской Федерации обозначены в качестве национальных приоритетов [3], что в обозримом будущем актуализирует вопросы совершенствования методологии управления информацией и внедрения принципов информационного взаимодействия в государственном секторе.

Об исключительной важности открытости органов государственной власти говорится в программной статье Президента РФ В.В. Путина «Демократия и качество государства». Согласно тексту статьи, демократия не может ограничиваться только участием граждан в электо- ральных процедурах. Для осуществления подлинной демократии необходимо обеспечить возможность для граждан влиять на властные институты, для этого, в свою очередь, требуется создать эффективные коммуникационные каналы между властью и обществом. Поэтому, в целях обеспечения постоянной обратной связи, органы власти должны предоставлять гражданам максимальную информацию о собственной деятельности. Это предоставит гражданскому обществу рычаги, необходимые для влияния на государство, и, соответственно, обеспечит высокое качество демократии в России [4]. Также, по словам Президента, без дееспособного государства невозможно устойчивое развитие общества, а информационная открытость является обязательным условием создания дееспособного государства. Следовательно, открытость органов государственной власти является важным катализатором развития общества в целом.

Важным показателем степени информационной открытости государственных структур является организационно-правовое обеспечение деятельности органов власти в обозначенной сфере.

На данный момент в Российской Федерации представлен ряд основополагающих нормативно-правовых актов, регулирующих развитие принципов и механизмов информационной открытости органов государственной и муниципальной власти.

В первую очередь стоить упомянуть Конституцию Российской Федерации. В соответствии с ч. 2 ст. 24 Конституции РФ органы государственной власти и органы местного самоуправления, их должностные лица обязаны обеспечить каждому возможность ознакомления с документами и материалами, непосредственно затрагивающими его права и свободы [5]. Конституция РФ стала прочной базой для развития эффективного взаимодействия между государственной властью и гражданским обществом.

В Федеральном законе от 27.07.2006 № 149-Ф3 «Об информации, информационных технологиях и о защите информации» регламентируются основы правового регулирования отношений в сфере информации, в том числе информации о деятельности государственных органов и органов местного самоуправления и свободный доступ к такой информации, кроме случаев, установленных федеральными законами [6].

Ключевым нормативно-правовым актом, устанавливающим принципы получения доступа к информации о деятельности органов власти, является Федеральный закон от 09.02.2009 № 8-Ф3 «Об обеспечении доступа к информации о деятельности государственных органов и органов местного самоуправления» [7]. К этим принци- 
пам относятся: открытость и доступность информации, достоверность, свобода поиска, получения, передачи и распространения информации. В соответствии с данным законодательным актом, государственные органы и органы местного самоуправления должны в обязательном порядке предоставлять всю информацию об их деятельности в открытом доступе, кроме случаев, когда данные сведения составляют государственную или иную охраняемую законом тайну.

В 2012 году Президентом РФ Дмитрием Медведевым был подписан Указ «О рабочей группе по подготовке предложений по формированию в Российской Федерации системы «Открытое правительство» [8]. В связи с этим, началась её разработка, в основу которой были заложены принципы открытого взаимодействия между властью и обществом. Основной целью стало вовлечение институтов гражданского общества в процесс принятия управленческих решений и участие в экспертизе значимых для общества проектов.

Здесь следует также обозначить опыт создания Департамента Правительства РФ по формированию системы «Открытое правительство», включенный в структуру Аппарата Правительства РФ распоряжением Правительства РФ от 4 июня 2012 г. № 891-р [9]. В данном Департаменте функционирует отдел внедрения механизмов системы «Открытого правительства в субъекты Российской Федерации», который осуществляет методическую и организационную помощь региональным органам власти в сфере внедрения проекта «Открытый регион».

Помимо вышесказанного, следует говорить о создании сайта Data.gov.ru. Данный сайт является крупной библиотекой, где содержатся в открытом доступе наборы государственных данных. Они сгруппированы по трем уровням - федеральному, региональному и муниципальному, что позволяет гражданам получать равный доступ к необходимой информации о деятельности органа власти любого уровня.

Также в рамках работы над системой «Открытого правительства» был создан официальный сайт Экспертного совета при Правительстве РФ open.gov.ru. Экспертный совет при Правительстве РФ - «консультативный орган, который был сформирован для осуществления экспертизы значимых для гражданского общества решений Правительства Российской Федерации, федеральных органов исполнительной власти, правительственных, межведомственных комиссий и советов, а также для генерации различных вопросов со стороны институтов гражданского общества для рассмотрения с Председателем Правительства РФ и федеральными органами исполнительной власти» [10]. Его создание играет важную роль в развитии механизмов взаимодействия между ин- ститутами гражданского общества и властными структурами.

Еще одним важным шагом на пути обеспечения реализации принципов информационной открытости стало принятие в 2014 году Концепции открытости федеральных органов исполнительной власти [11], которая стала основой для Стандартов информационной открытости. Вышеупомянутая концепция устанавливает следующие принципы открытости федеральных органов исполнительной власти: принцип информационной открытости, принцип понятности, принцип вовлеченности гражданского общества и принцип подотчетности, осуществление которых способствует реализации потребностей и интересов граждан, активному взаимодействию между органами государственной власти, экспертным сообществом и институтами гражданского общества.

В последние годы развития принципов информационной открытости в органах государственной власти электронные ресурсы становятся основными источниками открытой и актуальной информации о деятельности государственных структур для институтов гражданского общества. Здесь следует говорить о так называемой цифровой трансформации государственного управления. Под цифровой трансформацией мы подразумеваем совокупность изменений в стратегии, моделях осуществления деятельности и постановке целей и задач, претворяемых в жизнь посредством интеграции в повседневную деятельность цифровых технологий. Внедрение цифровых технологий в работу всех органов государственной власти становится не только трендом, но и реальной необходимостью.

Траектория цифровой трансформации системы государственного управления содержится в национальной программе «Цифровая экономика Российской Федерации» [12] на 2018-2024 годы, которая определяет основные цели и задачи государственной политики в данной области. В настоящее время в рамках этой программы реализуется федеральный проект «Нормативное регулирование цифровой среды», предусматривающий разработку и принятие ряда нормативно-правовых актов, направленных на снятие первоочередных барьеров, которые препятствуют развитию информационной открытости.

В 2019 году были предприняты следующие важные шаги:

- Определение правового статуса самоисполняемых контрактов («смарт-контрактов»), внедрение понятия цифровых прав;

- Облегчение порядка предоставления и получения нотариальных услуг благодаря информатизации большинства услуг; 
- Изменение системы функционирования удостоверяющих центров, внедрение института доверенной третьей стороны, предоставление возможности применения «облачной» электронной подписи;

- Внедрение «реестровой» модели предоставления государственных услуг в сфере лицензирования [13].

Следовательно, можно говорить, что на сегодняшний день в нашей стране проводится обширная работа по формированию теоретико-методологических и нормативно-правовых основ информационной открытости деятельности государственных структур. Были разработаны соответствующие законодательные акты, обеспечивающие возможность доступа к информации о деятельности органов власти и их официальных лиц, которая подлежит размещению в открытом доступе, и за счет подотчетности власти обществу, повышающей уровень доверия между гражданским обществом и государством.

Однако, несмотря на то, что информационная открытость системы государственной власти нашла свое закрепление в ряде нормативно-правовых актов Российской Федерации, обобщение результатов теоретических исследований и анализ прикладных аспектов реализации деятельности по информационной открытости в органах государственной власти позволяют выделить некоторые организационно-правовые ограничения в повышении открытости государственных органов.

До сих пор на стадии рассмотрения в Государственной Думе Российской Федерации находятся законопроекты о цифровом взаимодействии при заключении договоров страхования, о проведении эксперимента по переходу на электронный кадровый документооборот, о цифровых финансовых активах и т.д., которые также призваны обеспечить расширение проникновения принципов информационной открытости и повышение качества предоставления государственных услуг. Согласно экспертным оценкам, наиболее весомым является влияние устоявшихся представлений об иерархической системе управления и негибкости процесса законотворчества. Так как разрабатываемые законопроекты зачастую «ломают традиционные устои», реализовать их крайне сложно.

Федеральным законом от 09.02.2009 № 8-Ф3 «Об обеспечении доступа кинформации одеятельности государственных органов и органов местного самоуправления» устанавливается перечень обязательной к раскрытию информации. В этом перечне приводится значительное количество информации, в первую очередь о самом органе государственной власти, его нормотворческой де- ятельности, статистическая информация, выступления руководителей органа, информация о кадровом обеспечения и работе с обращениями. Представляется целесообразным раскрывать и дополнительную информацию, выходящую за рамки данного перечня. В частности, речь может идти об информации, связанной с общественной деятельностью органа государственной власти, процессом принятия решений, предложения по включению представителей гражданского общества в процесс принятия решений.

Изучение теоретических аспектов реализации принципов информационной открытости органов государственной власти позволяет также акцентировать внимание на проблеме организационного характера развитии навыков для внедрения механизмов информационной открытости. Развитие информационной открытости государственных структур в других странах указывает на необходимость пересмотра основных ценностей в сфере цифрового развития: в числе первоочередных задач государства должно быть закреплено положение о продвижении цифрового и технического образования, а также формирование нового типа личности подрастающего поколения, в основе обучения которых будут находиться современные информационно-коммуникационные технологии.

Обобщая вышесказанное, необходимо отметить, что Российская Федерация проделала значительный путь в развитии информационной открытости органов государственной власти. Многие государственные структуры повышают собственную открытость, делают шаги навстречу гражданскому обществу.

Вместе с тем, изучение теоретических аспектов реализации принципов информационной открытости органов государственной власти позволяет сделать вывод о недостаточном уровне компетенции государственных служащих для внедрения механизмов информационной открытости в их деятельность, что говорит о необходимости продвижения цифрового образования как среди государственных служащих, так и среди представителей гражданского общества. Представляется целесообразным уделить должное внимание рассмотрению законопроектов, регулирующих применение специфических механизмов информационной открытости. Более того, органам государственной власти, помимо общей информации, следует представлять дополнительные сведения о их деятельности в открытом доступе, что позволит расширить возможности для диалога между официальными представителями государства и гражданского общества. Таким образом, информационная открытость органов власти в Российской Федерации имеет большие перспективы для эффективного развития. 


\section{ЛИТЕРАТУРА}

1. Институциональное доверие [Электронный ресурс] // АНО «Левада-Центр».— Режим доступа: https://www.levada.ru/2019/10/24/institutsionalnoedoverie-5/.- Загл. с экрана.

2. узьмин, А. В. Основы обеспечения открытости в деятельности органов государственной власти в РФ / А. В. Кузьмин // Ученые записки Тамбовского отделения РоСМУ.— 2018.— № 9.—С. 188-197.

3. 06 утверждении Доктрины информационной безопасности Российской Федерации [Электронный ресурс]: [указ Президента Российской Федерации от 5 декабря 2016 г. № 646]. - Доступ из справ.-правовой системы «КонсультантПлюс».

4. Демократия и качество государства. Владимир Путин о развитии демократических институтов в России [Электронный ресурс] // Коммерсантъ. — Режим доступа: https://www.kommersant.ru/doc/1866753.— - Загл. с экрана.

5. Конституция Российской Федерации [Электронный ресурс]: [принята всенародным голосованием 12 декабря 1993 г.: по состоянию на 31 мая 2020 г.].Доступ из справ.-правовой системы «КонсультантПлюс».

6. 06 информации, информационных технологиях и о защите информации [Электронный ресурс]: [федер. закон Рос. Федерации от 27 июля 2006 г. № 149 Ф3: принят Гос. Думой Федер. Собр. Рос. Федерации 8 июля 2006 г.: одобр. Советом Федерации Федер. Собр. Рос. Федерации 14 июля 2006 г.: по состоянию на 31 мая 2020 г.]. - Доступ из справ.-правовой системы «КонсультантПлюс».

7. 06 обеспечении доступа к информации о деятельности государственных органов и органов местного самоуправления [Электронный ресурс]: [федер. закон Рос. Федерации от 9 февраля 2009 г. № 8-Ф3: принят Гос. Думой Федер. Собр. Рос. Федерации 21 января 2009 г.: одобр. Советом Федерации Федер. Собр. Рос. Федерации 28 января 2009 г.: по состоянию на 31 мая 2020 г.]. — Доступ из справ.-правовой системы «КонсультантПлюс».

8. Что такое открытые данные? [Электронный ресурс] // Портал открытых данных Российской Федерации.— Режим доступа: https://data.gov.ru/chto-takoeotkrytye-dannye. - Загл. с экрана.

9. 0 рабочей группе по подготовке предложений по формированию в Российской Федерации системы «Открытое правительство» [Электронный ресурс]: [указ Президента Российской Федерации от 8 февраля 2012 г. № 150].—- Доступ из справ.-правовой системы «КонсультантПлюс».

10. Экспертный совет при Правительстве РФ [Электронный ресурс]: [сайт].— - Режим доступа: https://open.gov.ru/.

11. $0 б$ утверждении Концепции открытости федеральных органов исполнительной власти [Электронный ресурс]: [распоряжение Правительства Российской Федерации от 30 января 2014 г. № 93-р].—- Доступ из справ.-правовой системы «КонсультантПлюс».

12. Национальная программа «Цифровая экономика Российской Федерации» [Электронный ресурс]: [утвержден президиумом Совета при Президенте Российской Федерации по стратегическому развитию и национальным проектам 24 декабря 2018 г. № 16)].— Режим доступа: http://government.ru/ rugovclassifier/614/events/.

13. Нормативное регулирование цифровой среды [Электронный ресурс] // Официальный сайт Минэкономразвития России — Режим доступа: https://www. economy.gov.ru/material/directions/gosudarstvennoe_upravlenie/normativnoe_regulirovanie_cifrovoy_sredy/.— Загл. с экрана. 